\title{
Oral paracoccidioidomycosis as a differential diagnosis of oral cancer
}

\author{
Sergio Sargenti Neto ${ }^{[1]}$, Luiz Fernando Barbosa de Paulo ${ }^{[1]}$ and Roberta Rezende Rosa ${ }^{[1]}$
}

[1]. Departamento de Diagnóstico Estomatológico, Universidade Federal de Uberlândia, Uberlândia, MG.

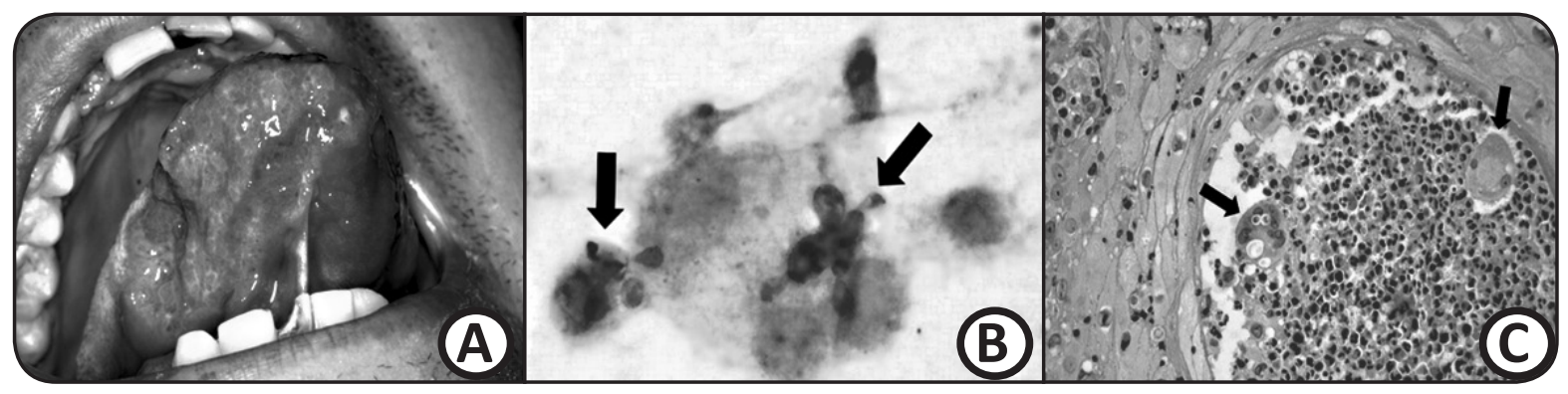

A 40-year-old caucasian man presented with a symptomatic large ulcer in his tongue, with a granular purpuric surface, which appeared three months before admission to the out- patient clinic. He also complained of weight loss, fever and anorexia. The patient has been a smoker and an alcohol addict for 25 years. No productive cough was observed and a chest x-ray did not show areas of nodular infiltration. Intraoral examination showed evidence of an ulcer, in the form of mulberry-like granulomatous lesions on the border of the tongue measuring about $4.0 \mathrm{~cm}$ (Figure A). Also, a gingival linear erythema dispersed in the maxilla was identified and bone lesions in the jaws were not evident.

The diagnostic hypothesis was squamous cell carcinoma. An exfoliative cytology and incisional biopsy were performed. The main morphological findings in the cytological exam were the presence of spherullous, birefringent, and multiple-budded fungi (Paracoccidioides brasiliensis), surrounded by Langhan's giant cells, epithelioid cells, and nonspecific inflammatory cells (Figure B). Biopsy specimens completed the cytological evaluation and showed granuloma formations with multinucleated giant cells and a polymorphonuclear with vacuoles suggestive of infection (Figure $\mathbf{C}$ ). The diagnosis was oral paracoccidioidomycosis. The treatment was performed with itraconazole $300 \mathrm{mg}$ daily for 12 months. In 24-month follow-up, there is no evidence of disease.

This report emphasize that physicians must realize the possibility of paracoccidioidomycosis and squamous cell carcinoma at this risk population. In this sense, some specific characteristics of the diagnosis process could help to identify both lesions.

O paciente de 40 anos apresentou-se com grande úlcera sintomática em língua, com superfície granular avermelhada, originada há três meses, associada com sintomas sistêmicos, como perda de peso, febre e anorexia. 0 paciente relatava tabagismo e

Address to: Dr. Luiz Fernando Barbosa de Paulo. Ambulatório de Cuidados Especiais às Doenças Estomatológicas/FO/UFU. Rua Acre 941, 38450-319 Uberlândia, MG, Brasil. Phone: 5534 3213-8595

e-mail: luizfbpaulo@gmail.com

Received in 14/07/2012

Accepted in 17/08/2012 consumo de álcool por 25 anos. Não foi observada tosse produtiva e uma radiografia de tórax não apresentou área de infiltração nodular. O exame intraoral evidenciou úlcera granulomatosa com aspecto moriforme em borda de língua, medindo cerca de 4,0cm (Figura A). Além disso, eritema gengival linear disperso na maxila foi identificado e lesões ósseas nos maxilares não eram evidentes.

A hipótese diagnóstica foi de carcinoma de células escamosas. Uma citologia esfoliativa e biópsia incisional foram realizadas. Os principais achados morfológicos no exame citológico foram a presença de fungos birrefringentes com múltiplos brotamentos e formato esférico (Paracoccidioides brasiliensis), envolvidos por células gigantes tipo Langhans, células epitelioides e células inflamatórias inespecíficas (Figura B). A biópsia concluiu a avaliação citológica e mostrou formação de granulomas com células gigantes multinucleadas e polimorfonucleares com vacúolos sugestivos de infecção (Figura C). O paciente recebeu $300 \mathrm{mg}$ de itraconazol por dia durante 12 meses. Os 24 meses de acompanhamento forneceram evidências de que a doença fora curada.

Este relato enfatiza que os médicos devem perceber a possibilidade da paracoccidioidomicose e carcinoma de células escamosas, nesta população de risco. Neste sentido, algumas características específicas do processo de diagnóstico podem ajudar a identificar as lesões.

\section{TITLE IN PORTUGUESE}

\section{Paracoccidioidomicose oral como diagnóstico} diferencial do câncer bucal

\section{REFERENCES}

1. Almeida OP, Jacks Jr J, Scully C. Paracoccidioidomycosis of the mouth: an emerging deep mycosis. Crit Rev Oral Biol Med 2003; 14:377-383.

2. Martinez R. Paracoccidioidomycosis: the dimension of the problem of a neglected disease. Rev Soc Bras Med Trop 2010; 43:480.

3. Loth EA, CastroSV, SilvaJR, Gandra RF. Occurrence of 102 cases of paracoccidioidomycosis in 18 months in the Itaipu Lake region, Western Paraná. Rev Soc Bras Med Trop 2011; 44:636-637. 